\title{
Fertility trends and differentials in the Nordic countries - Footprints of welfare policies and challenges on the road ahead
}

\author{
Marit Ronsen and Kari Skrede*
}

\begin{abstract}
This paper summarises the core findings of a recently finished network project on fertility dynamics and family policies in the Nordic countries. The network explored the findings of previous and ongoing separate research activities from a comparative perspective and carried out specially designed, comparative analyses for this project. Based on the network results and other existing research we review the collected evidence of the potential impacts of Nordic welfare policies on fertility. With cohort fertility levels around replacement level, the Nordic countries apparently have less to worry about concerning their future population development than most other European countries. Yet, some elements in the present trends suggest that there are still challenges ahead. In particular, we argue that the current fertility pattern may not be compatible with gender equality, a main goal for our societies.
\end{abstract}

\section{Background and main research questions}

In the Nordic countries, women enjoy a high degree of participation in working life while at the same time giving birth to a relatively large number of children. This is often taken to indicate that the Nordic family policy model has been successful in attaining one of its goals - gender equality - while at the same time contributing to sustaining a reasonable fertility level. However, the latter has never been a clearly expressed goal but is regarded as a welcome side effect. In this article, we discuss the sustainability of the Nordic model of family welfare in more detail. The discussion is, to a large extent, based on the main findings of a recently finished comparative project that builds on the research activities of a network of scholars in demography and the social sciences working on issues

\footnotetext{
* Marit Rønsen, (author of correspondence), Research Department, Statistics Norway, PO Box 8131 Dept, NO-0033 Oslo, Norway. Email: Marit.Ronsen@ssb.no Kari Skrede, Research Department, Statistics Norway, Oslo, Norway.
} 
related to the fertility dynamics and family policies in the Nordic countries. ${ }^{1}$ The main activities of the network project were twofold: First, it explored further the findings of previous and ongoing separate research activities from a comparative perspective. Second, it carried out specially designed, comparative analyses based on data that were harmonised for this project. The following three main research questions were addressed:

1) Do the fertility trends of the Nordic countries point to a common Nordic fertility model with similar and converging characteristics or to structural differences and diverging trends?

2) To what extent can similarities and differences in fertility at the country level be explained by similarities or differences in family policies?

3) To what extent does the Nordic model of family welfare and gender equality represent a robust and sustainable road in relation to present challenges posed by social and demographic developments within Nordic societies?

A thorough examination of these issues and detailed results of the network analyses can be found in Neyer et al. (2006) and Andersson et al. (2008). In this article, we shall briefly summarise the core findings of the network project and give a short presentation of the analytical approach, methods and data used. Next, we shall review more broadly the collected evidence of potential impacts of family policies on fertility in the Nordic countries, drawing also on previous research by network members and other scholars. Finally, we shall discuss some findings that point to challenges for the future, even if the Nordic model of family welfare seems to support a reasonably high fertility level. As we have argued elsewhere (Rønsen and Skrede 2006), one challenge is the possible incompatibility of the present fertility pattern with gender equality, a main goal for our societies. Another challenge is related to men's family formation and recent evidence of a stronger socio-economic selection into fatherhood (Skrede $2003,2004)$. In the conclusion, we shall reflect on the implications these findings have for the future social and demographic development and call attention to areas for future research.

\section{Analytical approach, methods and data material}

The comparative analyses of the network project covered four Nordic countries: Denmark, Finland, Norway and Sweden. Differences and similarities in fertility patterns were analysed from two perspectives: (i) the trend in period fertility rates

\footnotetext{
The network consists of researchers from the Max Planck Institute for Demographic Research (Gerda Neyer), Statistics Norway (Trude Lappegård, Marit Rønsen and Kari Skrede), Stockholm University (Gunnar Andersson) and Aalborg University (Lisbeth B. Knudsen). The project administration, network activities and Norwegian analyses were supported by the Welfare Research Programme of the Nordic Council of Ministers (grant 149810-S99), which is gratefully acknowledged.
} 
from 1970-2000 and (ii) the development of cohort fertility (completed fertility) of women born 1935-1969 (see Neyer et al. 2006 and Andersson et al. 2008 for more details). The reproductive years of these birth cohorts overlap with the calendar period studied and their completed fertility may thus, to a large extent, be regarded as the outcome of the observed period patterns. Moreover, the female cohorts in our analyses entered their reproductive life at different calendar periods with different social and cultural environments, including different political discussions concerning family policy and gender equality. Analysing fertility development from both a period and a cohort perspective thus provided better insights into potential linkages between the Nordic model of social welfare and fertility development.

Both the period analyses and the cohort analyses were based on individuallevel data from linked administrative registers. We had access to data on the whole female populations of Denmark, Norway and Sweden and a ten per cent sample of that of Finland. The data were further harmonised to obtain maximum comparability across countries. The harmonisation involved creating analysis datasets that were as similar as possible, both as regards the population included and the definition of variables used. ${ }^{2}$ We had full demographic histories of the cohorts we studied, with childbirths recorded with the accuracy of one month. Socio-economic characteristics were available for the 1980s and the 1990s and data on these characteristics were provided on an annual basis. They stem from various administrative registers such as tax registers with information on annual taxable earnings, registers on different social-security transfers and educational registers. Our analyses were based on data on native-born women.

The period trends were analysed by birth order (first, second and third birth) and the parity-specific fertility rates were standardised using multivariate hazard rate models. The models included controls for both demographic and socioeconomic characteristics (women's age, age of youngest child (2nd and 3rd birth), educational level and income). In the corresponding cohort analyses, we studied fertility differentials along three dimensions: (i) between birth cohorts, (ii) between social groups according to women's attained educational level and (iii) between Nordic countries. The analyses were based on genuine birth cohorts of women, i.e. we observed the birth histories of women born in each of the four Nordic countries and calculated cohort fertility measures from age-specific parity progression rates over women's reproductive years, censoring women who died or emigrated at the time of death or emigration. ${ }^{3}$

When using multivariate models (period fertility analyses), the harmonisation also includes similar model specification and application of the same program package.

3 This approach is different from that of e.g. published statistics on cohort fertility in national and international sources, which are normally based on data on the resident female populations of fertile ages in specific calendar years. It also differs from previous analyses of cohort fertility in the Nordic countries where cohort data were constructed from period statistics (Björklund 2006; Frejka and Calot 2001). 
Furthermore, as we had access to longitudinal information on education, we were able to condition on past educational attainment when analysing subsequent cumulated fertility. We thus avoided the common problem of seeking to explain fertility behaviour at a certain age by the educational level reported and possibly attained at a later stage, which is a form of anticipatory analysis that can produce misleading results on the interrelationship between education and fertility (see e.g. Hoem and Kreyenfeld 2006a, 2006b). The definitions of attained educational level were harmonised across countries using the 1997 International Standard Classification of Education (ISCED97). We distinguished between the following groups: low education (ISCED codes 0-2: primary and lower secondary), medium education (ISCED codes 3-4: upper secondary) and high education (ISCED codes 5-6: tertiary). A more detailed presentation of the cohort analyses and a discussion of the comparability of educational attainment can be found in Andersson et al. 2008.

\section{Findings}

\subsection{Converging or diverging country trends?}

The period fertility trends of the four Nordic countries have developed quite similarly, except for Finland (which had more fluctuations in the 1970s and early 1980s) and Sweden (which had much stronger fluctuations in the 1990s) (Fig. 1). Fertility declined in most of the region during the 1970s. In the early 1980s, the period total fertility rate (TFR) in Norway and Sweden had stabilised at around 1.6-1.7 children per woman, with a so far all-time low in 1983 for both countries. In Denmark, fertility continued to decline into the early 1980s, but hit a historic low in exactly the same year as in Norway and Sweden, with a TFR just below 1.4. In contrast to the other Nordic countries, Finland had a short period of rising TFR in the early 1980 s, succeeded by a temporary fall to a level of about 1.6 in 1986-1987.

From around the mid-1980s, fertility started to rise in all countries, but the rise was much more pronounced in Sweden than in the other countries. Likewise, while trends in Denmark, Finland and Norway stabilised or fell slightly in the 1990 s, Sweden continued its roller coaster pattern with sharply falling rates during most of the decade followed by a new up-turn towards the end of the 1990s. By 2005, the Swedish TFR had again converged with those of the other Nordic countries at levels around 1.8. 
Figure 1:

Total Fertility Rate of the Nordic countries, 1960-2005

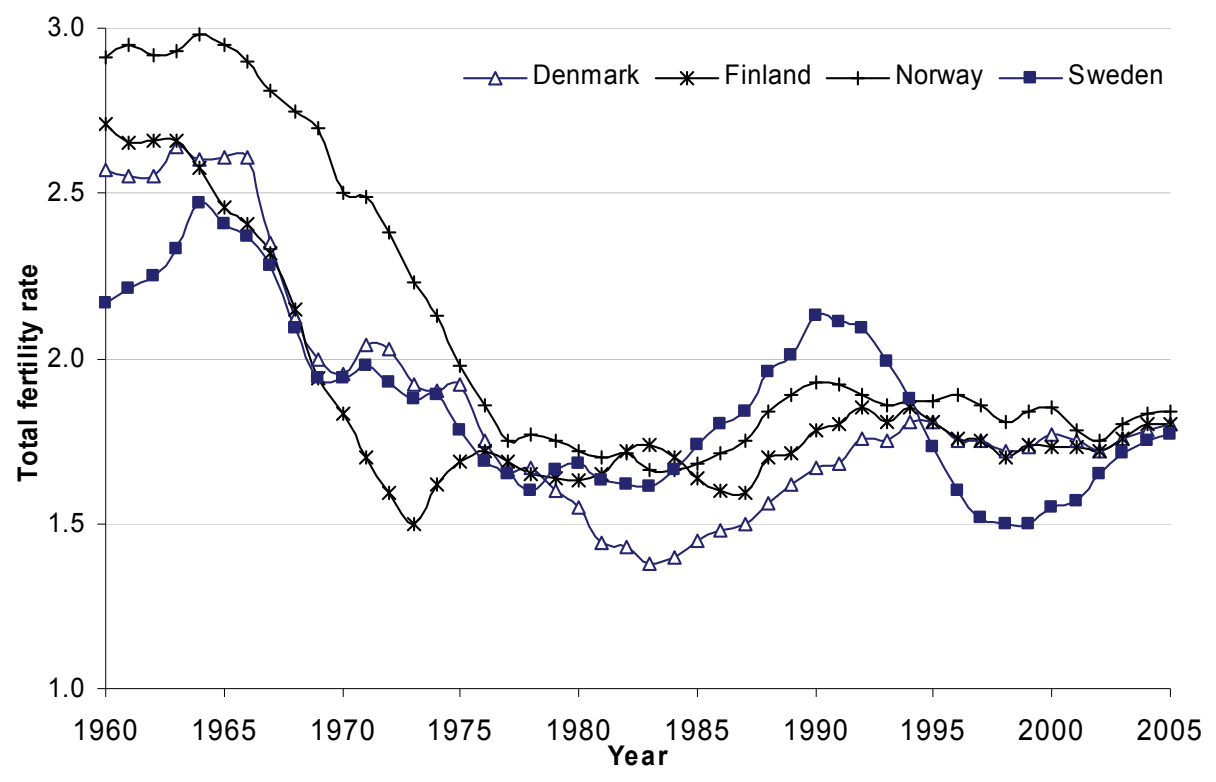

Source: Statistics Finland, Statistics Denmark, Statistics Norway and Statistics Sweden

\subsubsection{Lower age at first birth in Norway}

A closer examination of the underlying trends by parity (birth order) also revealed fairly similar patterns though with certain country peculiarities. Common for all countries was the trend of decreasing first-birth rates among young women in their teens and twenties and increasing rates among older women, i.e. women continued to postpone first births in all countries but recuperated more and more after age 30 . However, even if trends were similar, there were some interesting country divergences in levels, as the rates among young women were distinctly higher in Norway and the rates among older women distinctly lower in Finland (Andersson 2004; Neyer et al. 2006).

Lower first-birth rates were reflected in a lower median age at first birth among women born between 1935 and 1969 in Norway than among those born in the other countries (Fig. 2). In most cohorts, Finnish women had the highest median age, followed by Swedish and Danish women. In the 1965-69 cohort, median age at first birth was about 29 in Finland, about 28 in Sweden and Denmark and about 26.5 in Norway. In all countries, the childbearing age increased by 3.5-4 years across cohorts born since the Second World War. Finnish women were forerunners in the shift towards later childbearing, followed by Swedish and Danish women born in the early 1950s and finally by Norwegian 
women born in the late 1950s. The ranking of Denmark is, however, a bit uncertain, as we did not have data for older Danish cohorts.

Figure 2:

Age at which 50 per cent of women became mothers, cohorts born in 1935-1969

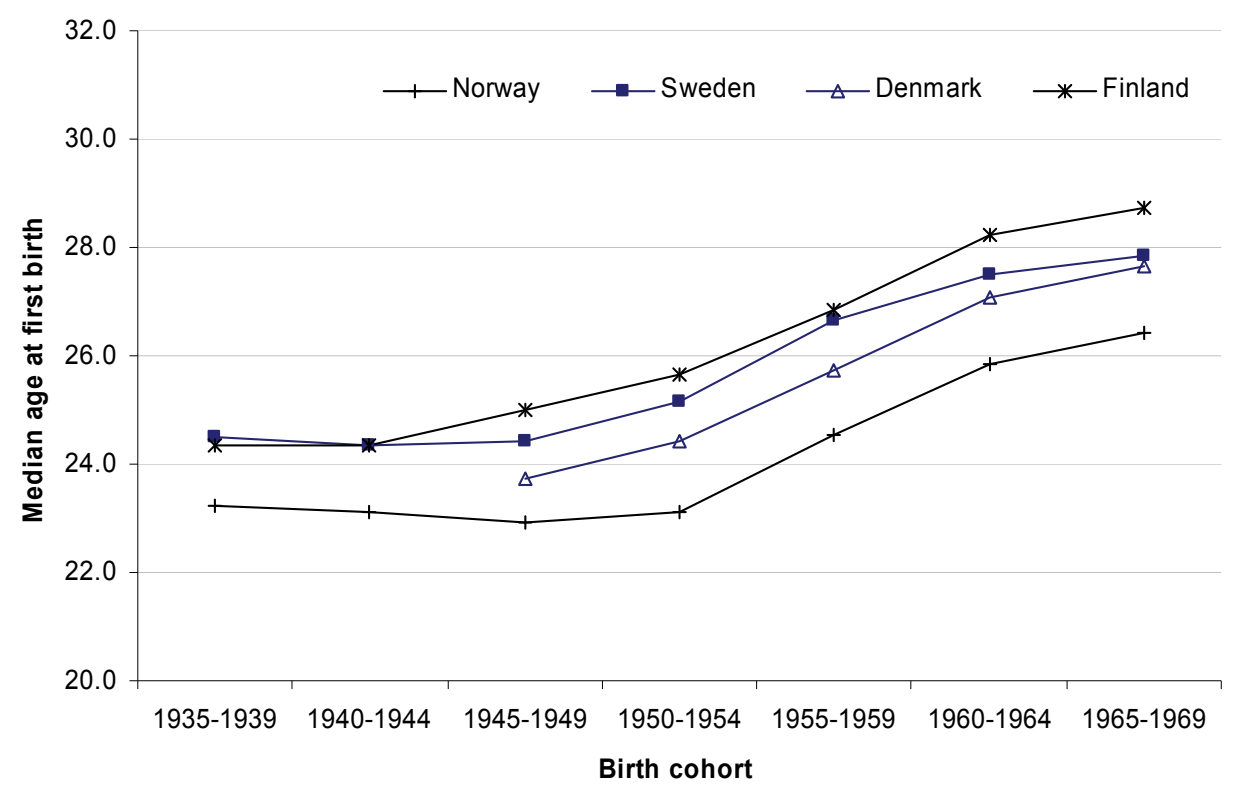

Source: Andersson et al. 2008

There was very little convergence in median childbearing age between the countries as the shift towards higher ages was quite parallel in cohorts born from the late 1950s onwards. However, due to a levelling off in the increase in median age in the youngest Swedish cohorts, the Danish 1965-69 cohort is now on par with its Swedish peers.

The study showed that Norway has the largest differences in age at first birth by education (Fig. 3). Between women with high (university and college) and low (primary and lower secondary school) education in the youngest cohort, the age difference was about seven years in Norway, as compared to around five years in Denmark, Finland and Sweden.

In Norway and partly also in Sweden, the educational differences increased somewhat across cohorts, while they were fairly stable in Denmark and Finland. Norwegian women started childbearing earlier than other Nordic women at each educational level, but women with low education in Norway had an especially low childbearing age. In the youngest cohort, their median age was just below 22 years, while it was around 25 years in Sweden, Finland and Denmark. Moreover, this divergence did not diminish across the cohorts. 
Women with high education had the most equal median ages and showed fairly parallel postponement across countries. In Sweden, Denmark and Finland, postponement was also more or less parallel across educational groups. In Norway, on the other hand, the process started among the highly educated (in the 1950-54 cohort), followed by women with medium education (in the 1955-59 cohort) and, finally, by women with low education (in the 1960-64 cohort).

\section{Figure 3:}

Age at which 50 per cent of women became mothers, by educational level at age 30, cohorts born in 1945-1969
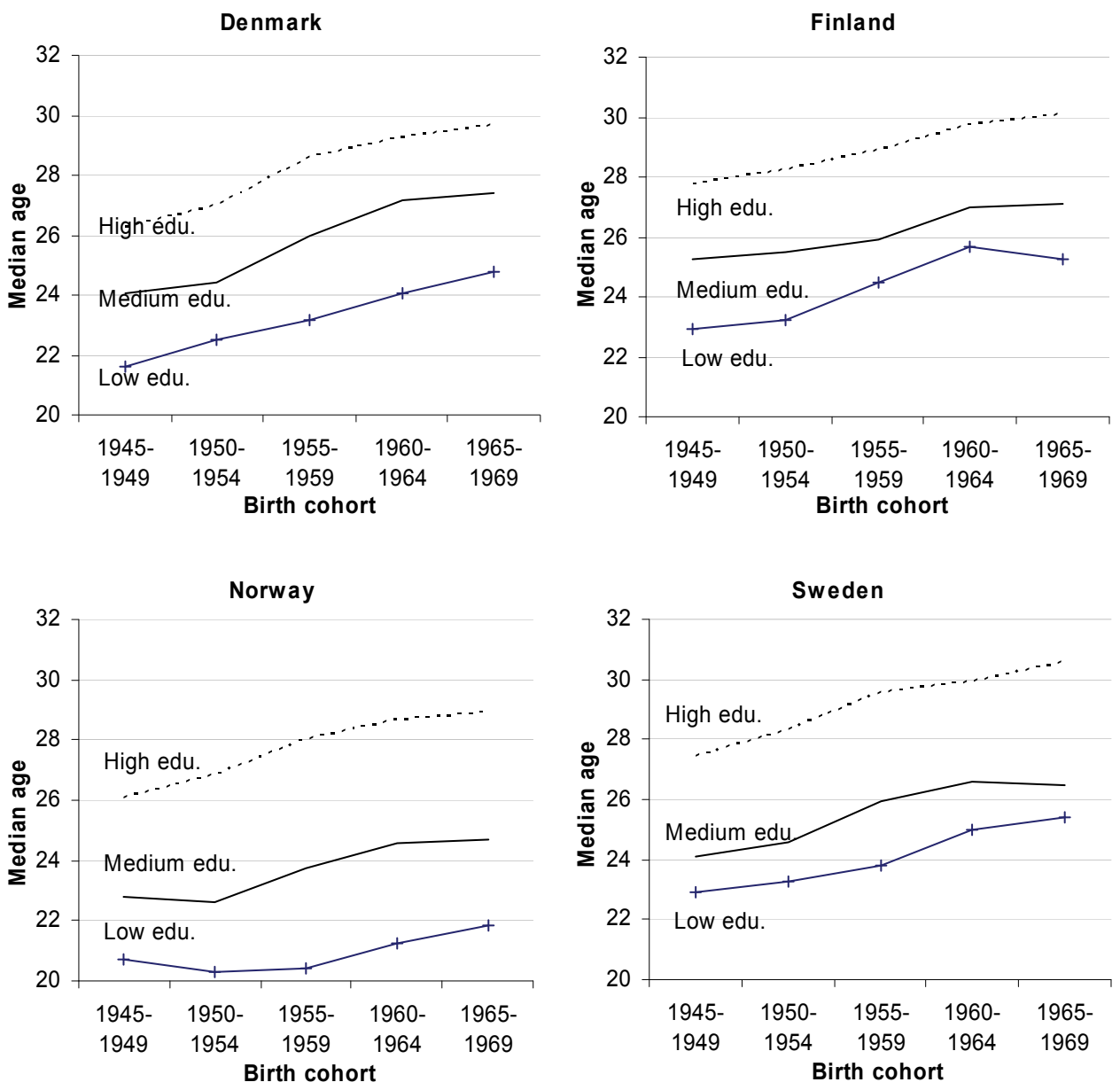

Source: Andersson et al. 2008 


\subsubsection{Higher childlessness in Finland}

Lower first-birth rates among women in their 30s in Finland indicate that recuperation was slower in this country and that more women ended up without having children. This was reflected in a higher proportion of childless women than in the other countries - about 17 per cent compared to 14-15 per cent in Denmark and Sweden and about 12 per cent in Norway in the 1955-59 cohort (Fig. 4). Childlessness increased most in Denmark, but except for a narrowing of the gap between Denmark versus Sweden and Finland, there was little convergence in childlessness between the countries.

\section{Figure 4:}

Childlessness at age 40, female cohorts born in 1935-1959

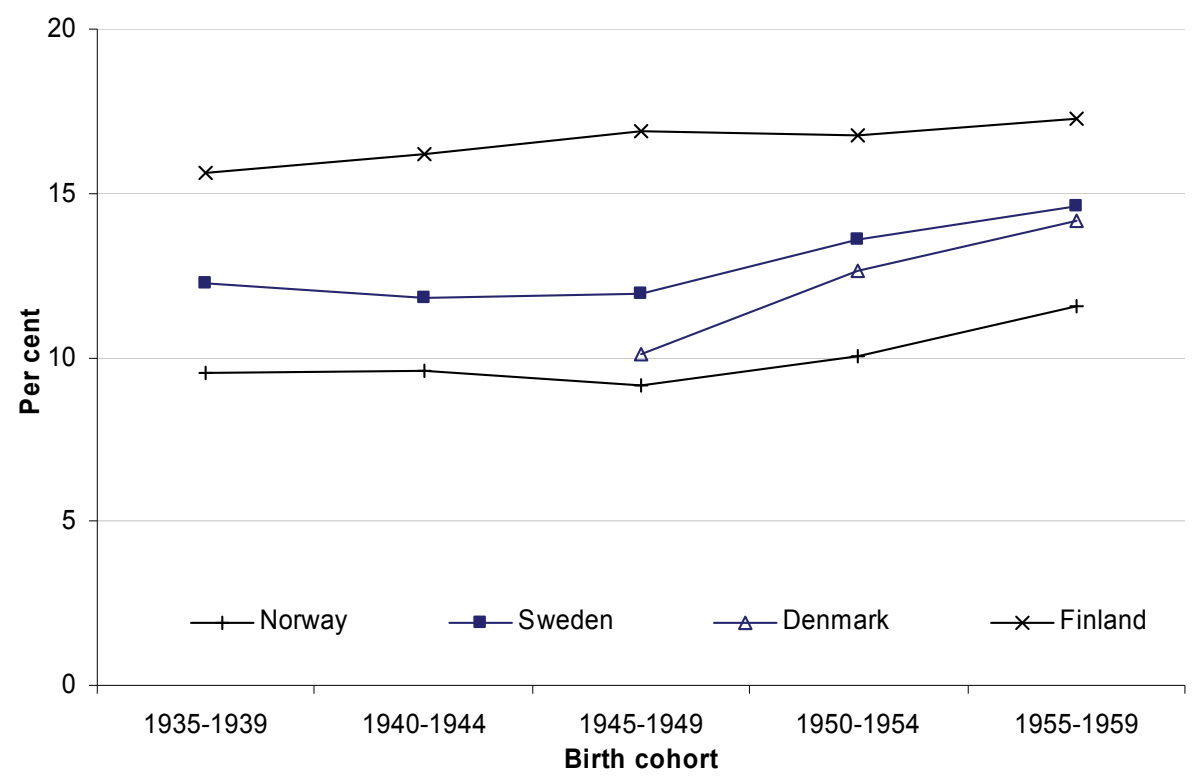

Source: Andersson et al. 2008

As in the case of age at first birth, Norway was the country with the largest educational differences in childlessness (Fig. 5). In the late 1950s cohorts, the proportion with no children was about nine per cent among women with low education and about 15 per cent among women with high education. 
Figure 5:

Childlessness at age 40, by educational level at age 30, female cohorts born in 19451959
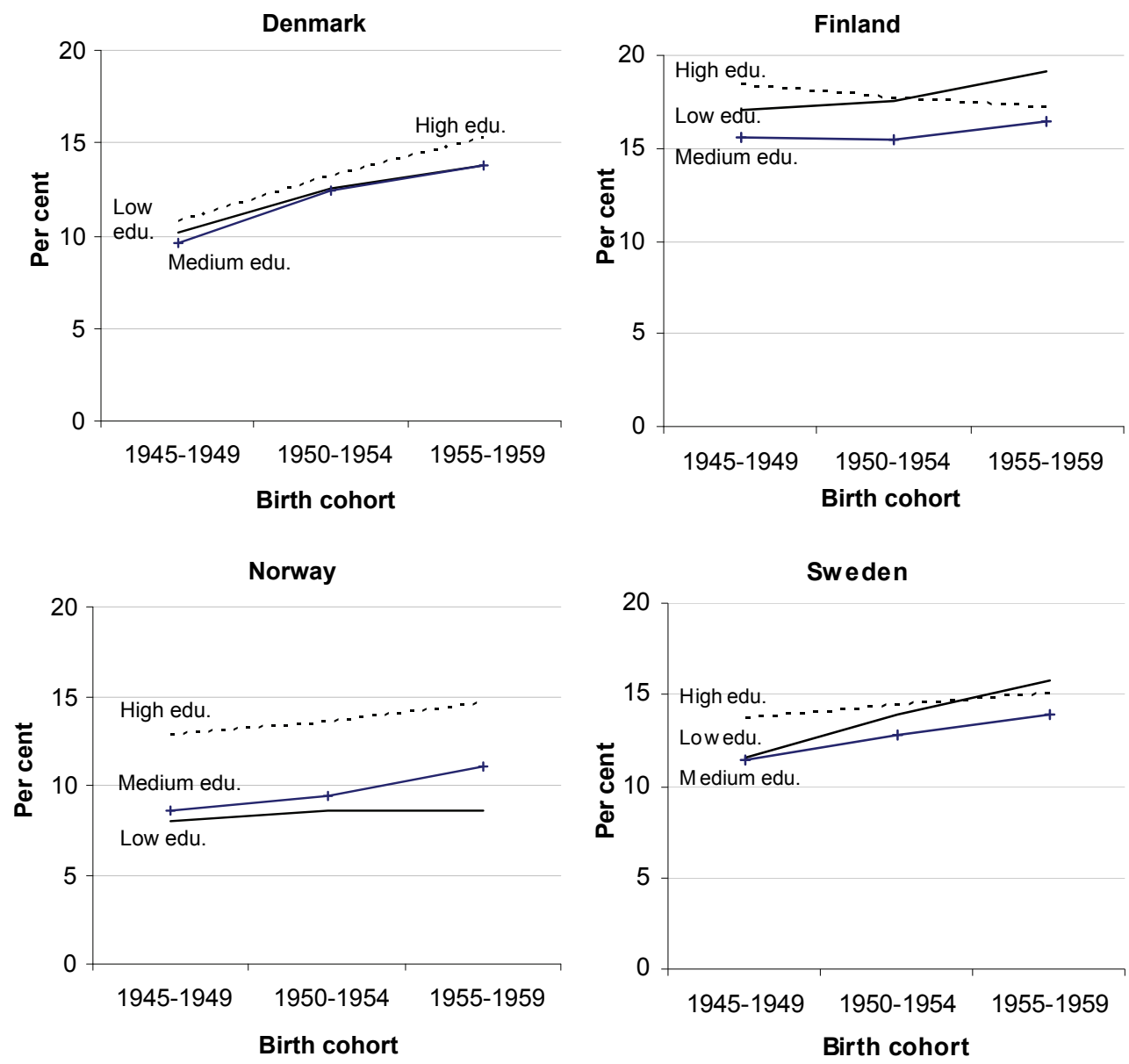

Source: Andersson et al. 2008

Interestingly, the level of childlessness among highly educated women was about the same in Denmark, Sweden and Norway in the youngest cohorts. However, in Denmark, childlessness was not very different among those with low education and in Sweden childlessness was even higher in the group with low than in the group with high education. This was also the case in Finland where the proportion with no children in the youngest cohort was 19 per cent among the lowest educated and 17 per cent among the highest educated.

The country trends in childlessness across cohorts were quite divergent. In Denmark and Norway the proportion with no children increased more among highly educated women than among those with low education, resulting in larger 
differences between these two groups across cohorts born after the Second World War. Sweden saw a stronger increase in the proportion of childless women in the lowest education group, resulting in smaller educational differences and a shift in the top ranking from the highest to the lowest education group. In Finland, the same shift occurred and childlessness among highly educated women even decreased across cohorts.

\subsubsection{More fluctuations in period birth rates in Sweden, but more stable cohort fertility}

The period trends in second-birth rates were characterised by a greater variation between countries than those for first-birth rates (Andersson 2004; Neyer et al. 2006). Sweden saw a turn-around from falling to rising rates in 1977 with a very steep increase in the 1980s and a sharp decline in the 1990s. Norway, on the other hand, had a fairly stable trend throughout the entire study period though with a shift from moderately falling to weakly increasing rates in the same year as in Sweden, i.e. in 1977. Danish second-birth rates kept falling until the early 1980s, but then rose fairly strongly and levelled off during the 1990s. In Finland, secondbirth rates already started to increase in the early 1970s and the rise continued-in parallel with Denmark - during the 1980s, but with more of a turn-around to weakly falling rates in the 1990s. However, despite the different developments over the period, the countries' second-birth rates were converging at the turn of the century (Neyer et al. 2006).

The trends in third-birth rates were more parallel, but as in the case of second births, the shift from falling to rising rates in the first part of the period occurred earlier in Finland and later in Denmark as compared to Norway and Sweden, where 1977 once again marked the turning point. In the 1990s, third-birth rates stabilised in all countries except Sweden where they fell strongly until the end of the decade when there was a new up-turn. Since the late 1970s and until the mid1990s, the Danish rate was distinctly lower than the rates of the other countries, but at the turn of the century the level in Denmark was about the same as in Sweden. The Finnish and Norwegian third-birth rates were higher and fairly similar. These countries had a rather parallel development since the end of the 1970s (Neyer et al. 2006).

In spite of fluctuating period trends, completed fertility (cohort fertility) of women who gave birth during this period was quite stable (Fig. 6). In fact, Sweden - the country with most fluctuations in period trends - also had the most stable cohort trend. This was mainly due to the fact that completed fertility had already been quite low in the oldest Swedish cohorts (about 2.05 children among women born before the Second World War). Among women born after the War, the final number of children varied between 1.9 and 2. Cohort fertility in Finland was just as low in the old cohorts, but among the post-war cohorts the final 
number of children varied somewhat more, from about 1.7 in the late 1940s cohorts to about 1.9 in the late 1950s cohorts. Denmark and Norway had a larger and quite parallel fall in cohort fertility though from different levels - about 2 and 2.2 children in the 1945 cohort, respectively. Interestingly, for the mid-1950s cohorts, a slight upward trend in completed fertility could be observed in all countries, which levelled off for the early 1960s cohorts in Norway and Sweden. Norwegian women still had the highest cohort fertility in the youngest cohorts (around 2.05 children), while the corresponding figure in the other countries was just above 1.9 in Finland and Sweden and just above 1.8 in Denmark. Thus, recent cohorts of Nordic women gave birth to a number of children that was just below replacement level.

\section{Figure 6:}

Cohort Total Fertility at age 40, female single-year cohorts born in 1935-1963

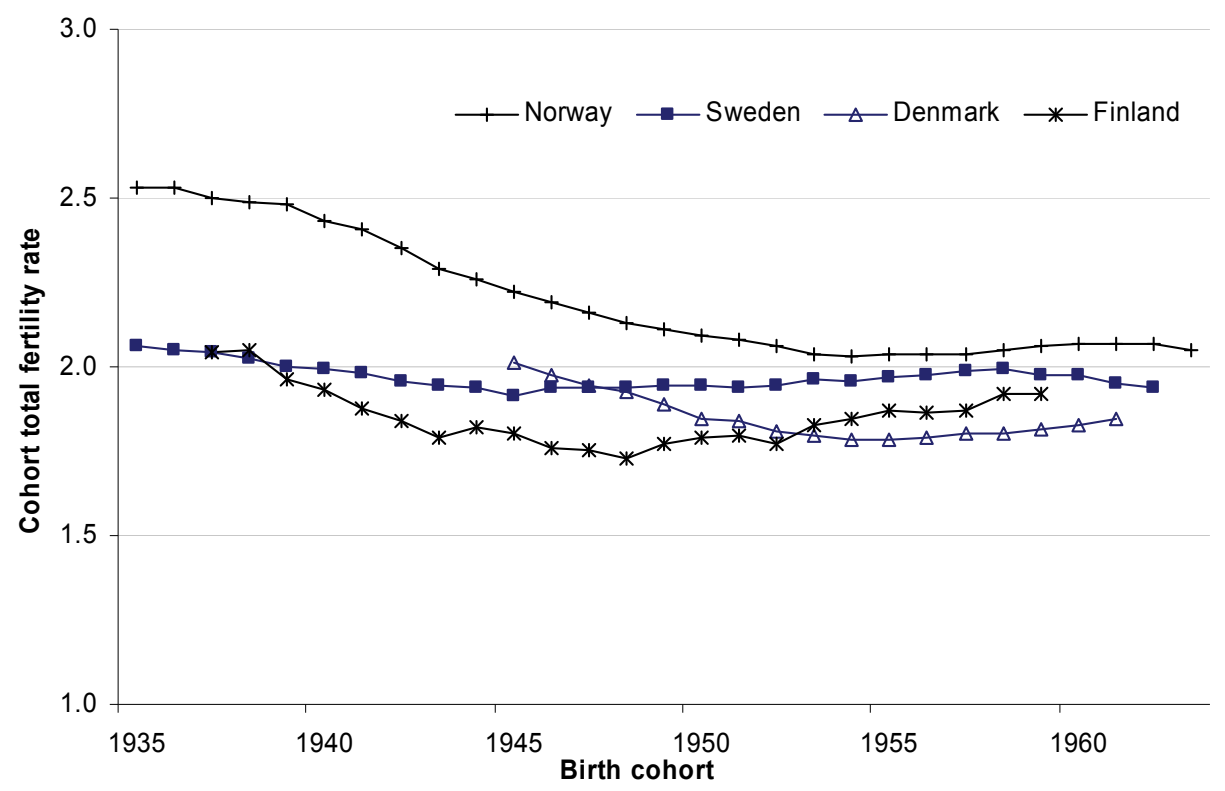

Source: Andersson et al. 2008

Educational differences in completed fertility were largest in Norway, but there was convergence across cohorts born in 1945-1959, mainly because of a larger decrease in the number of children born by women with low education (Fig. 7). A similar convergence also took place in Denmark. In Finland and Sweden, educational differences were smaller. In Finland, cohort fertility increased in all groups across cohorts born after the Second World War, but less so in the group with low education than in the groups with higher education. In the youngest Finnish cohorts, women with medium education had the highest number of children, while in Sweden the women in the group with low education 
still completed their fertile years with the largest number of children, just like in Denmark and Norway.

\section{Figure 7:}

Cohort total fertility at age 40 , by educational level at age 30 , female cohorts born in 1945-1959
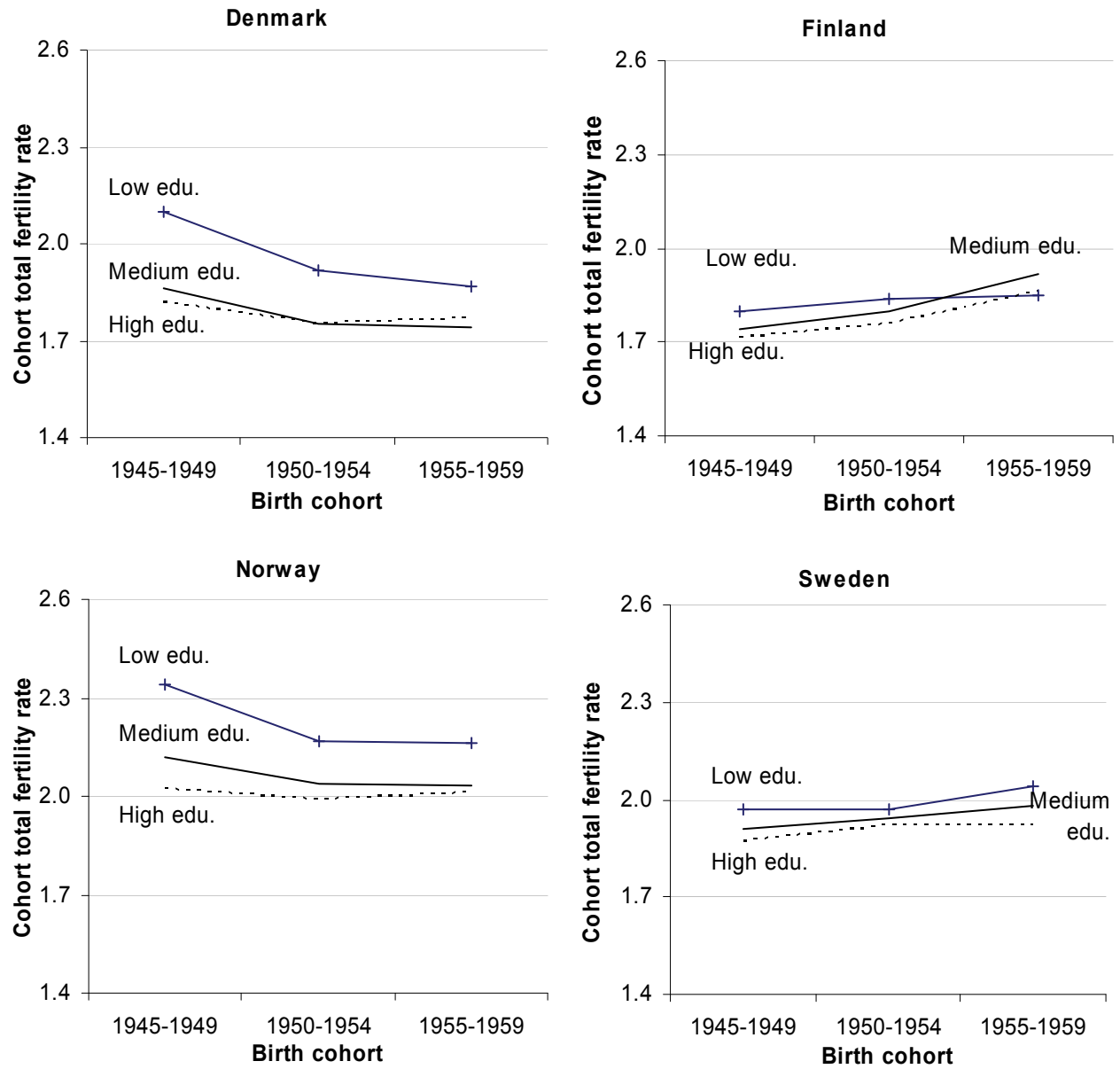

Source: Andersson et al. 2008

Thus, we could observe differences in fertility patterns between educational groups in all countries, but the differences were largest in Norway. However, a general pattern in all countries was that the educational differences declined with respect to the final number of children. There was also a certain convergence between highly educated women across countries regarding childlessness, median age at first birth and final number of children. 
On the whole, fertility trends in the Nordic countries seemed sufficiently similar to suggest that there is a common 'fertility regime'. One limitation of this conclusion is, of course, the absence of comparisons with other European countries, but such comparisons are difficult to make due to a lack of comparable statistics on cohort fertility divided by educational level. However, a recent comparative analysis of Sweden and Austria revealed large variations in birth patterns between these two countries (Neyer and Hoem 2008). In spite of very similar childlessness rates at the country level, the proportion of women with no children among the highly educated was much higher in Austria than in Sweden and the discrepancy in childlessness between women with high and low education was much more pronounced in Austria (ibid). A similar pattern also seems to prevail in Britain, where first childbearing among women with medium and higher education was shown to occur much later than in Norway and France, while low-educated women have levels of early first childbearing that are on par with Norway but much higher than in France (Rendall et al. 2005). Against this background, a common Nordic fertility model seems to be a logical assumption, but more comparative analyses would be necessary to draw a final conclusion here.

\section{What is the impact of family policies?}

The possible connection between policies encouraging parenthood and fertility has attracted increasing interest over the past decades, both in demographic research and on the political agenda of the ageing societies in the western industrialised world. The Nordic combination of high levels of female labour force participation with relatively high levels of fertility has given impetus to the debate in this area and has prompted the notion that family policies play a role in generating this fortunate situation.

The Nordic countries have shared many similarities in their political, economic and social development in the period after the Second World War in terms of educational expansion, labour market structures and participation, as well as in the general content of their welfare policies. However, several studies have documented that there are considerable differences between the Nordic countries with regard to the historical development of their family policy programmes and the extent to which present family policies also integrate gender equality as an explicit political goal (Borchorst 1994; Kjeldstad 2001; Leira 1992; Sainsbury 2001; Skrede 1999). Such differences in the development of opportunity structures for parenthood and parenthood practices provide an analytic framework of contextual dynamics for exploring policy effects on fertility. Yet, one should bear in mind that, in part, the possible links between public policies and fertility are likely to be indirect effects and that it is difficult to 
measure indirect effects related to the broader context of economic, social and political developments.

The findings of our Nordic network project summarised above seem to suggest that such indirect effects played a role in keeping fertility at a reasonably high level. The fact that cohort fertility remained stable and even somewhat increased in younger cohorts is one indication in this direction. In spite of increasing age at first birth, the younger cohorts recuperate the fertility level of somewhat older cohorts at ages 30 and above. Another indication is the good recuperation record even among well-educated women, resulting in small or declining educational differences in completed fertility in all countries. Moreover, the fertility patterns among highly educated women are converging across countries, as evidenced by age at first birth, childlessness and final number of children (Andersson et al. 2008). The examination of period trends by parity further reveals an interesting reversal in second-birth rates in three out of four Nordic countries exactly in the year when the modern system of parental leave was introduced with rights to take leave for both parents and a more generous income compensation (Neyer et al. 2006).

Supportive evidence for the notion that Nordic welfare policies have a certain pro-natalistic effect also comes from analyses of specific policy programmes by individual network members and other scholars. Probably most evident is the effect of the so called 'speed premium' in Sweden (Hoem 1993). This is a unique feature of the Swedish parental leave system granting mothers the same benefit level as with the previous child if they have another child within 30 months (before 1986: 24 months), even if they do not return to work between the two births. As was to be expected, this has encouraged mothers to have their second and third child sooner (Andersson 1999, 2004; Berinde 1999; Oláh 2003). An interesting additional finding from Sweden (Duvander and Andersson 2006; Oláh 2003), which was also documented for Norway (Duvander et al. 2007) later on, is that women are more likely to have a next child if the father took parental leave when they had their first child. This suggests that measures which encourage fathers' active participation in child care may stimulate fertility. A positive effect, though only on the likelihood of a third birth, is also evident for mothers who took extended leave. Interestingly, higher third-birth rates among women who took extended leave in connection with a special home care allowance were also found for Finland (Vikat 2004) and similar positive effects were recently documented for mothers who use a related cash-for-care benefit in Norway (Aasve and Lappegård forthcoming). Such positive effects of the use of family policies may, however, also be due to selection, as more family-oriented fathers and mothers may be more inclined to have another child and take more leave.

Evidence from Norway further indicates that increasing day care supply may have a slightly positive effect on third births, which, however, is most pronounced at low levels of day care coverage and among highly educated women (Kravdal 1996). The latter is an interesting finding but may partly reflect that highly 
educated mothers were a driving force behind the vast expansion of day care centres. For Sweden, researchers found no significant positive effects on fertility of neither the availability nor the price of day care (Andersson et al. 2004). However, the latter study only covers two years (1996-1997) and moreover, as pointed out by Rindfuss et al. (2007), there may be unobserved local factors that affect both fertility decisions and the local availability of day care centres. Using fixed-effects models to control for such endogeneity, the latter authors find a clear, positive effect of day care availability on the transition to motherhood for Norway. Analyses of the importance of the length and economic compensation of parental leave programmes in the Nordic countries are harder to find. One comparative study of Finland and Norway renders some support for the hypothesis that parental leave extensions may stimulate fertility (Rønsen 2004). The effect is most significant for Finland, which had more extensions during the period under analysis (about 1960-1990). Moreover, it is mainly limited to the probability of giving birth to a second or third child.

The accumulated evidence from past research as well as the recently finished Nordic network project thus corroborate the hypothesis that welfare policies have positive effects on fertility. However, as demonstrated by the Swedish trend in the 1990 s, a generous family policy programme is no guarantee for a high fertility level. In the early 1990s, Sweden experienced a slack in its economy, which soon led to a sharp rise in unemployment. Young people and people with low education were hit particularly hard. For the first time ever, financial support to families was also cut back. Soon after, fertility declined from 2.1 children per woman in 1992 to about 1.5 in 1997. Thus, economic cycles and economic prospects also clearly have an impact on fertility. The observed negative effect of rising unemployment is probably a result of both poorer income prospects for the present and-possibly even more important - a stronger feeling of insecurity regarding the future.

However, as suggested in comparisons of Sweden and Finland, adverse macro-economic conditions need not have the same adverse effects on fertility in all countries. In Finland, unemployment also rose very quickly and to higher levels than in Sweden in the early 1990s while fertility remained at a relatively high level. Evidently, the recession did not have a noticeable influence on the childbearing behaviour of Finnish women. One explanation for the divergent fertility response in Finland and Sweden may be that the Finnish welfare state was able to retain most of its important functions during the recession. Besides, the home care allowance (HCA) scheme had been fully implemented just before the downturn of the economy. This may have encouraged some women to have a child and take extended child care leave with the support of the HCA while the labour market conditions were unfavourable (Vikat 2004). A couple of Swedish studies suggest that fertility in Sweden may exhibit stronger pro-cyclic patterns because its family policy is more closely linked to prior employment (Björklund 2006; Jonsson and Dlab 2003). Compared to Finland, the income replacement in 
the parental leave scheme is higher in Sweden, while the minimum amount received by those with little or no previous income is much lower.

Thus, there is also evidence that different policy programmes at the country level contributed to differences in fertility behaviour. The divergent fertility trends in Finland and Sweden during the recession in the early 1990s are one indication in this direction. Another example is the more generous transitional allowance granted to lone parents in Norway, which may be one reason for the distinctly higher first-birth rates among young Norwegian women (Rønsen and Skrede 2006). Like the Finnish home care allowance, it may also have served as a counter-cyclical measure during the spell of relatively high youth unemployment in Norway in the early 1990s, which did not seem to have a strong impact on firstbirth rates. Moreover, among the Nordic countries, Norway offers the highest cash benefit at childbirth for mothers with no or little labour market experience prior to birth and the most generous support arrangements for students who have children (Bjørnberg et al. 2006). Hence, fairly generous cash benefits or minimum allowances may serve as a counter-cyclical measure and have a stabilising effect on fertility during times of recession.

\section{How sustainable is the Nordic model of family welfare?}

With cohort fertility around or close to replacement level, it is reasonable to conclude that the Nordic countries have to worry less about their present fertility levels than most other European countries. However, this does not mean that the present Nordic fertility trends represent a robust and sustainable road in all respects vis-à-vis challenges posed by the social and demographic development. These challenges are influenced both by the structural changes in the fertility patterns and by the current ambitions and goals of welfare policies.

First of all, from a demographic perspective, some of the challenges are related to the effects of population ageing. Cohort fertility rates around replacement level will only reduce and not reverse them. Increasing rates of childlessness will inevitably lead to higher levels of childless elderly people in the future, with a corresponding growth in the demand for care services for the elderly population, as children remain a critical source of help for frail old people (Attias-Donfut et al. 2005). One aspect of this development is a stronger increase in childlessness among men than among women in younger Norwegian and Swedish cohorts (Statistics Sweden 2002; Skrede 2004). The challenges may thus be even stronger than judged by the development of the fertility trends for the female cohorts, as childless men have been found to be particularly disadvantaged with regard to health and the support potential of their networks (Dykstra and Hagestad 2007).

So far, there has been little research on the fertility patterns of Nordic men, but recent analyses from Norway indicate both a stronger socio-economic 
selection into fatherhood and more multi-partner fertility (having children with more than one woman). One may speculate whether a more pronounced 'recirculation' of eligible men is part of this picture (Skrede 2003, 2004). Furthermore, the rise in male childlessness concerns men at all educational levels, including the highly educated. A conjecture in this connection is that part of the postponement of motherhood by highly educated women may be related to difficulties in finding a man who is willing to share parental duties at a more equal level than what has been described as gender equality light (Skrede 2005). By this we mean a division of labour still common among Nordic couples today: Women do most of the housework and child care work and men do most of the market work, even if both partners are active on the labour market. However, women take longer career breaks and often work part-time after the children are born.

An alternative explanation for the increased postponement of fatherhood among younger highly educated men is the possible existence of negative attitudes from employers towards their active fatherhood role. Earlier research for Norway indicates, for example, that employers of men working in career jobs in the private sector often have negative views on longer parental leave than the socalled 'daddy's quota' (Brandth and Kvande 2005). ${ }^{4}$ From this perspective, the postponement can be seen as a strategy for establishing a solid foothold in the labour market prior to fatherhood.

Secondly, from a political perspective, there are challenges related to gender equality, which was declared a main goal for the Nordic models of family welfare. As we argued recently, some elements of the present fertility trends give reason to question the sustainability of the development in relation to this goal (Rønsen and Skrede 2006). Our arguments are mainly based on closer analyses of the development in Norway and Sweden, two countries that have higher cohort fertility than Finland and Denmark, but also higher levels of part-time work and more pronounced gender segregation on the labour markets (TemaNord 1999:514). For both countries, recent analyses showed that women with an education for the female-dominated professions in the public sector contribute with higher levels of fertility than women with an education for the less gendersegregated or male-dominated sectors (Hoem, Neyer and Andersson 2006; Lappegård 2001, 2006). The differences in fertility by type of education suggest that a great deal of the good recuperation record at cohort level may be explained by a family-friendly, gender-segregated labour market and an underlying selection of women with strong preferences for children and for work in a familyfriendly context into occupations in these sectors. This assumption is also supported by earlier research indicating that a main contributing factor to the observed positive association between education and higher-order births in

4 The daddy quota is a part of the parental leave exclusively reserved for fathers. When introduced in 1993, it was four weeks and has been six weeks since 2006. These weeks are lost if they are not taken by the father. 
Norway is an unobserved positive selection into motherhood of family-oriented, highly educated mothers (Kravdal 2001).

The postponement of first birth and increased rates of childlessness in younger cohorts are additional indications of preference heterogeneity both in educational choice and in entrance into motherhood. A recent analysis of the association between education and young Norwegian women's transition to motherhood suggests that there is a career adjustment effect in women's entry into motherhood related to their field of education (Lappegård and Rønsen 2005). This may be due to differences in the opportunity costs of a career break by sectors, but also to preference heterogeneity. Increasing educational differences further suggest that long parental leaves and generous family benefits may fit better with a career track in the public sector and within female-dominated professions than among highly educated young women in the private sector and within jobs and professions with more male competition.

Consequently, the current cohort fertility rates close to replacement level should not be taken as a litmus test, neither of the sustainability of the fertility development nor of the compatibility with gender equality in the long run. Firstly, the higher birth propensities are most pronounced among women one would expect (by their choice of education and occupation) to have relatively strong preferences for family and children, including willingness to reduce their paid work in the childrearing phases. Secondly, the current pattern of parenthood practices by mothers and fathers with small children indicates that gender equality light aptly describes the share of paid and unpaid work for the majority of couples with small children. We would therefore argue that it is more appropriate to speak about a gender equality deficit in the current birth patterns. By this we mean a fertility pattern which presupposes a gender equality light division of work between parents, and which therefore is not compatible with gender equality at home and on the labour market. If future generations of women are not willing or able to adapt to family and work in the same way, we may also see declining fertility rates in the Nordic countries. In terms of policy options, this calls for measures that promote a more balanced sharing of social reproduction costs between men and women as well as between the public and the private sector. Family policy schemes with incentives for fathers to take longer parental leaves are among such options, as are initiatives that advance the understanding of both private and public employers of the need for both fathers and mothers to be actively involved in the day-to-day care of their children.

From the perspective of gender equality, a gender equality light division of paid and unpaid work has positive aspects compared to a traditional single breadwinner model in terms of increased economic autonomy and a foothold in the labour market for part-time workers. However, with regard to progress towards gender equality it also contains pitfalls as it perpetuates the present gender-segmented labour market and the lower incomes of women compared to those of men. In this respect, the current fertility pattern also gives reason to 
doubt the compatibility with gender equality in the long run. Questions related to the unequal gender division of paid and unpaid work over the life-course should therefore not be neglected in the search for a sustainable demographic development in the future.

With regard to the sustainability of the Nordic model of family welfare, the continued research on patterns of family formation and fertility dynamics should include efforts to assess compatibility with gender equality. The research strategy should be twofold: The further exploration of fertility dynamics and parental sharing of the responsibility for child care should preferably be based on models and data on couples including occupation, labour market attachment and employment sector for both parents. Moreover, future research on family formation and childlessness should pay increased attention to variation in young men's attitudes to fatherhood and shared parental duties, as well as their transition to fatherhood by educational and occupational background. This type of research would provide deeper insights into the imbalances in the current division of the responsibility for social reproduction between the public and the private sector and between women and men.

\section{References}

Aassve, A. and T. Lappegård. Forthcoming. "Childcare cash benefits and fertility timing in Norway." European Journal of Population.

Andersson, G. 1999. "Childbearing trends in Sweden 1961-1997." European Journal of Population 15: 1-24.

Andersson, G. 2004. "Childbearing developments in Denmark, Norway, and Sweden from the 1970s to the 1990s: A Comparison.” Demographic Research 3(7): 153-176.

Andersson, G., A.-Z. Duvander, and K. Hank. 2004. "Do child-care characteristics influence continued child bearing in Sweden? An investigation of the quantity, quality, and price dimension." European Journal of Population 14(4): 407-418.

Andersson, G., M. Rønsen, L. Knudsen, T. Lappegård, G. Neyer, K. Skrede, K. Teschner, and A. Vikat. 2008. "Cohort fertility patterns in the Nordic countries." MPIDR Working Paper WP 2008-008, Rostock: Max Planck Institute for Demographic Research.

Attias-Donfut, C., J. Ogg, and F.-C. Wolff. 2005. "Family support." In: A. Börsch-Supan, H. Brugiavini, J. Jürges, J. Mackenbach, J. Siegrist, and G. Weber (eds.) Health, ageing and retirement in Europe: First results from the Survey of Health, Ageing and Retirement in Europe. Mannheim, Mannheim Research Institute for the Economics of Aging, pp. 171-178.

Berinde, D. 1999. "Pathways to a third child in Sweden." European Journal of Population 15: $349-378$.

Björklund, A. 2006. "Does family policy affect fertility? Lessons from Sweden.” Journal of Population Economics 19(1): 3-24.

Bjørnberg, U., S. Ólafsson, and G. B. Eydal. 2006. "Education, employment and family formation: Differing patterns." In: J. Bradshaw and A. Hatland (eds.) Social policy, 
employment and family change in comparative perspective. Cheltenham, Edward Elgar, pp. 199-219.

Borchorst, A. 1994. "Welfare state regimes, women's interests and the EC." In: D. Sainsbury (ed.) Gendering welfare states. London, Sage Publications, pp. 26-44.

Brandth, B. and E. Kvande. 2005. "Fedres valgfrihet og arbeidslivets tidskulturer." Tidsskrift for samfunnsforskning 46: 35-54.

Duvander, A.-Z. and G. Andersson. 2006. "Gender equality and fertility in Sweden: A study on the impact of the father's uptake of parental leave on continued childbearing." Marriage and Family Review 39(1-2): 121-142.

Duvander, A.-Z., T. Lappegård, and G. Andersson. 2007. "Family policy and fertility: A comparative study on the impact of fathers' and mothers' use of parental leave on continued childbearing in Norway and Sweden." Unpublished manuscript.

Dykstra, P.A. and G.O. Hagestad. 2007. "Childlessness and parenthood in two centuries." Journal of Family Issues 28(11): 1518-1532.

Frejka, T. and G. Calot. 2001. "Cohort reproductive patterns in the Nordic countries." Demographic Research 5(5): 125-186.

Hoem, J. 1993. "Public policy as the fuel of fertility." Acta Sociologica 36: 19-31.

Hoem, J. and M. Kreyenfeld. 2006a. "Anticipatory analysis and its alternatives in lifecourse research. Part 1: The role of education in the study of first childbearing." Demographic Research 15(16): 461-484.

Hoem, J. and M. Kreyenfeld. 2006b. "Anticipatory analysis and its alternatives in lifecourse research. Part 2: Two interacting processes." Demographic Research 15(17): 485-498.

Hoem, J., G. Neyer, and G. Andersson. 2006. "Childlessness and educational attainment among Swedish women born in 1955-59." Demographic Research 14(15): 331-380.

Jonsson, A. and B. Dlab. 2003. "Sysselsätting och fruktsamhet i Sverige och Finland." Doctoral thesis. Nationalekonomiska institutionen, Stockholm University.

Kjeldstad, R. 2001. "Gender policies and gender equality.” In: M. Kautto, J. Fritzell, B. Hvinden, J. Kvist, and H. Uusitalo (eds.) Nordic welfare states in the European context. London, Routledge, pp. 66-97.

Kravdal, Ø. 1996. "How the local supply of day-care centers influences fertility in Norway: A parity-specific approach.” Population Research and Policy Review 15: 201-218.

Kravdal, Ø. 2001. "The high fertility of college educated women in Norway: An artefact of the separate modeling of each parity transition." Demographic Research 5(6): 187 215.

Lappegård, T. 2001. "Valg av utdanning - valg av livsløp." Tidsskrift for samfunnsforskning 3:409-435. (SJEKKE)

Lappegård, T. 2006. "Impact of labour market participation and employment structure on mothers' second- and third-birth rates in contemporary Norway." Paper III in Studies on fertility and childcare in contemporary Norway, Doctoral theses. Faculty of Social Science, Oslo, University of Oslo, pp. 95-114.

Lappegård, T. and M. Rønsen. 2005. "The multifaceted impact of education on entry into motherhood." European Journal of Population 21: 31-49.

Leira, A. 1992. Welfare states and working mothers. The Scandinavian experience. Cambridge (England), Cambridge University Press. 
Neyer, G. and J. Hoem. 2008. "Education and permanent childlessness: Austria vs. Sweden; a research note." MPIDR Working Paper WP 2008-007, Rostock: Max Planck Institute for Demographic Research.

Neyer, G., G. Andersson, J. Hoem, M. Rønsen, and A. Vikat. 2006. "Fertilität, Familiengründung und Familienerweiterung in den nordischen Ländern." In: H. Bertram, H. Krüger, and K. Spiess (eds.) Wem gehört die Familie der Zukunft? Expertisen zum 7. Familienbericht der Bundesregierung. Opladen, Verlag Barbara Budrich, pp. 207-233.

Oláh, L. S. 2003. "Gendering fertility: Second births in Sweden and Hungary." Population Research and Policy Review 22: 171-200.

Rendall, M., C. Couet, T. Lappegård, I. Robert-Bobée, M. Rønsen, and S. Smallwood 2005. "First births by age and education in Britain, France and Norway." Population Trends 121: 27-34.

Rindfuss, R. R., D. Guilkey, S. P. Morgan, Ø. Kravdal, and K. B. Guzzo. 2007. "Child care availability and first-birth timing in Norway." Demography 44(2): 345-372.

Rønsen, M. 2004. "Fertility and public policies - evidence from Norway and Finland." Demographic Research 10(10): 141-170.

Rønsen, M. and K. Skrede. 2006. "Nordic fertility patterns - compatible with gender equality?” In: A. L. Ellingsæter and A. Leira (eds.) Politicising parenthood: Gender relations in Scandinavian welfare state restructuring. Bristol, Policy Press, pp. 53-76

Sainsbury, D. 2001. "Gender and the making of the Norwegian and Swedish welfare states." Social Politics 8: 113-143.

Skrede, K. 1999. "Shaping gender equality - the role of the state: Norwegian experiences, present policies and future challenges." In: B. Palier and D. Bouget (eds.) Comparing social welfare systems in Nordic countries and France. Nantes, MIRE Vol. 4, Maison des Sciences de l'Homme, Ange-Guépin, pp. 169-199

Skrede, K. 2003. "Gender, Generations and Life Courses in the Melting Pot." In: J. Eriksen and L. Gulbrandsen (eds.) Natalie Rogoff Ramsøy (1924-2002): En pionér $i$ norsk og internasjonal sosiologi - et minneskrift. Oslo, NOVA-rapport 10/03.

Skrede, K. 2004. "Færre menn blir fedre." Økonomiske analyser 23/6: 57-68.

Skrede, K. 2005. "Foreldreskap i forandring - færre menn blir fedre." Tidsskrift for kjønnsforskning 29(2): 4-22.

Statistics Sweden. 2002. "Hur många barn får jag när jag blir stor? Barnafödande ur ett livsperspektiv." Demografiska rapporter 2002: 5.

TemaNord. 1999:514. "Women and men in the Nordic countries. Facts and figures 1999." Copenhagen, Nordic Council of Ministers.

Vikat, A. 2004. "Women's labor force attachment and childbearing in Finland." Demographic Research Special Collection 3, Article 8: 175-212. 